\title{
Pakistan's Trade and Trading Partners Using Gravity Model: A Static and Dynamic Panel Data
}

\author{
Sana Ullah*1, Adiqa Kausar Kiani² ${ }^{2} \&$ Muhammad Imran ${ }^{3}$ \\ ${ }^{1}$ Quaid-i-Azam University, Islamabad, Pakistan \\ ${ }^{2,3}$ Federal Urdu University, arts, science and technology, Islamabad, Pakistan
}

\begin{abstract}
This paper examines Pakistans trade flows using a gravity model for the period 2002-2015. We have selected the following major trade partners: China, UAE, Saudi Arab, United States, Kuwait, Malaysia, Japan, India, Singapore, Afghanistan and Iran. In this research, we employed static and dynamic econometric approaches. The results from the two approaches are similar, which showed economic size and distance have played a crucial role in bilateral trade. Furthermore, political globalization was found to be significant and played a vital role during the study period. These variables confirm that the theoretical models, Pakistan and Pakistan trade partner with economic masses, political globalization, and distance strongly effect trade liaison.
\end{abstract}

Keywords: Trade, Gravity model. Bilateral trade

JEL classification: C20, F12.

\section{Introduction}

Trade is an integral part of the developmental process of an economy. With globalization, many nations have liberalized their bilateral trade and removed barriers from trade. Globalization may be defined as enhancement of economic integration, free mobility of capital, border share and mobility of labor, etc. Pakistan started bargaining several bilateral and economic regional trade agreements with border countries in last two and three decades. Also, in this situation through bilateral trade, they also improved the peoples standard of living (Suvankulov and Guc, 2012; Xuegang, 2008).

The role of economic regional integration and free trade agreements has become an important ingredient in economic development. Many studies provide the empirical evidence on positive correlation between the regional trading agreements, market size, geographical distance, common border, language, culture and trade flows (Anderson, 2011; Samy and Dehejia, 2011; Serrano and Pinilla, 2012). The ASEAN, EU, NAFTA and WTO are successful examples of economic integration. The economic regional integration has derived the free trade agreement and economic development. The worlds aggregate demand has been growing at a sluggish rate, during 2015, due to declining commodity prices and snowballing instability of financial market in major economies. However, growth of import demand in Europe is declining, and as well as a weak

*Corresponding author.

Email: sana_ullah133@yahoo.com

http://www.jbrc.pk aggregate demand in the United States and Japan also becoming a low demand of agricultural commodity. As a result, developing countries, such as Pakistan, have seen demand for their exports cripple in this era and lower export earnings. As we know that, Pakistan is an agricultural economy, its exports are most of the time leading on agricultural commodity, like cotton \& cotton manufactures, rice, etc, as shown in table 1.1.

Although larger part of Pakistans exports goods are going to western countries such as, UK, Germany, France, Italy and Spain, etc. Furthermore, other major imports are Afghanistan, China, UAE, and USA. The share of exports to western countries like France, Italy, Spain, UK etc. remained comparatively stagnant in latest era. The share of export to U.A.E is witness to the fact that China and India are capturing this market, and so share of Pakistani exports have declined, as shown in table 1.2.

In the past, Pakistans agricultural commodity had enormous demand in international markets, but nowadays shortage of water and lack of better pesticides, along with the failure to cope with the changing trends in world markets, have affected the agricultural commodity demand and exports. Pakistan also faces a stiff competition from India and China for agricultural products. Pakistan mostly exports rice, fish and fish preparations, fruits, cotton yarn, fabrics, chemicals and pharmaceuticals; leather manufactures goods to the other countries.

Pakistan mostly imports from the China that is 23\% 
Table 1.1: Pakistan's Major Exports (\% share)

\begin{tabular}{lcccccc}
\hline Commodity & $\mathbf{2 0 0 9 - 1 0}$ & $\mathbf{2 0 1 0 - 1 1}$ & $\mathbf{2 0 1 1 - 1 2}$ & $\mathbf{2 0 1 2 - 1 3}$ & $\mathbf{2 0 1 3 - 1 4}$ & $\mathbf{2 0 1 4 - 1 5}$ \\
\hline Cotton Manufactures & 50.6 & 52.9 & 49.6 & 51.6 & 53.1 & $\mathbf{5 4 . 5}$ \\
Leather** & 4.5 & 4.4 & 4.4 & 4.7 & 5.1 & 4.8 \\
Rice & 11.3 & 8.7 & 8.7 & 7.8 & 7.6 & 8.5 \\
Sub-Total of three Items & $\mathbf{6 6 . 4}$ & $\mathbf{6 6 . 0}$ & $\mathbf{6 2 . 7}$ & $\mathbf{6 4 . 1}$ & $\mathbf{6 5 . 8}$ & $\mathbf{6 7 . 8}$ \\
Other items & 33.6 & 34.0 & 37.3 & 35.9 & 34.2 & 32.2 \\
Total & $\mathbf{1 0 0 . 0}$ & $\mathbf{1 0 0 . 0}$ & $\mathbf{1 0 0 . 0}$ & $\mathbf{1 0 0 . 0}$ & $\mathbf{1 0 0 . 0}$ & $\mathbf{1 0 0}$ \\
\hline
\end{tabular}

**: Leather \& Leather Manufactured. Source: Pakistan Bureau of Statistics

Table 1.2: Major Export Markets (Rs. \& US\$ Billion \& Percentage share)

\begin{tabular}{|c|c|c|c|c|c|c|}
\hline \multirow[t]{2}{*}{ Country } & \multicolumn{3}{|c|}{ 2013-14 } & \multicolumn{3}{|l|}{ 2014-15 } \\
\hline & Rs. & US\$ & \%Share & Rs. & US\$ & \%Share \\
\hline U.S.A & 381.5 & 3.7 & 15 & 374.4 & 3.7 & 16 \\
\hline China & 249.0 & 2.4 & 10 & 219.9 & 2.2 & 9 \\
\hline U.A.E & 180.0 & 1.7 & 7 & 102.9 & 1.0 & 4 \\
\hline Afghanistan & 192.5 & 1.9 & 7 & 198.8 & 1.9 & 8 \\
\hline United Kingdom & 161.5 & 1.6 & 6 & 160.2 & 1.6 & 7 \\
\hline Germany & 117.9 & 1.15 & 5 & 119.0 & 1.2 & 5 \\
\hline France & 42.7 & 0.4 & 2 & 38.2 & 0.4 & 2 \\
\hline Bangladesh & 71.8 & 0.7 & 3 & 70.7 & 0.7 & 3 \\
\hline Italy & 75.6 & 0.7 & 3 & 67.6 & 0.7 & 3 \\
\hline Spain & 72.0 & 0.7 & 3 & 81.7 & 0.8 & 3 \\
\hline All Other & $1,039.0$ & 10.1 & 40 & 964.1 & 9.5 & 40 \\
\hline Total & $2,583.5$ & 25.1 & 100 & 2397.5 & 23.7 & 100 \\
\hline
\end{tabular}

Source: Pakistan Bureau of Statistics

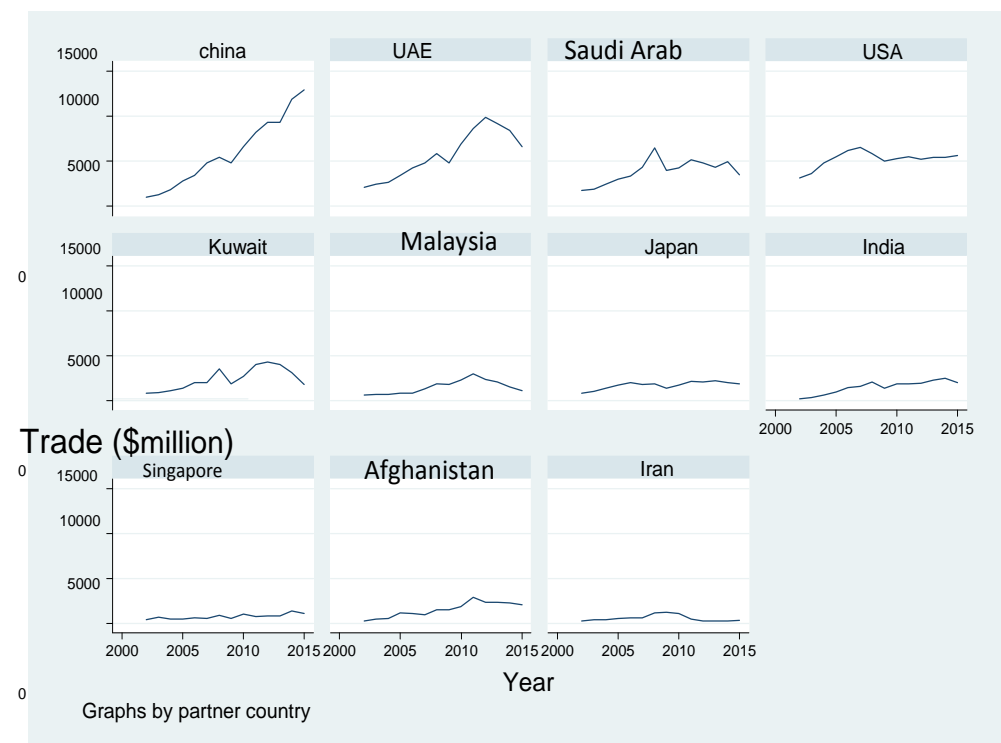

Figure 1: Bilateral trade between Pakistan and trade partners

\section{Source: Authors calculation}

in 2014-15. This ratio has massively increased in the last decade; in future this bilateral trade will also rise due to China-Pakistan Economic Corridor (CPEC). Pakistani imports are concentrated in a few markets like China, Saudi Arabia, Kuwait, UAE, where oil related commodities mostly imported from the Arabic countries. 
Table 1.3: Major Imports Markets (Rs. \& US\$ Billion \& Percentage share)

\begin{tabular}{lcccccc}
\hline Country & $\mathbf{2 0 1 3 - 1 4}$ & & \multicolumn{3}{c}{$\mathbf{2 0 1 4 - 1 5}$} \\
\hline U.A.E & Rs & US \$ & \% Share & Rs & US \$ & \% Share \\
China & 757.1 & 7.4 & 16 & 681.9 & 6.6 & 15 \\
Kuwait & 793.0 & 7.7 & 17 & 1053.0 & 10.2 & 23 \\
Saudi Arabia & 346.7 & 3.4 & 7 & 250.9 & 2.5 & 5 \\
Malaysia & 459.1 & 4.5 & 10 & 365.5 & 3.6 & 8 \\
Japan & 174.4 & 1.7 & 4 & 96.3 & 0.9 & 2 \\
India & 182.6 & 1.7 & 4 & 170.6 & 1.7 & 4 \\
U.S.A & 210.5 & 2.0 & 5 & 172.2 & 1.7 & 4 \\
Germany & 180.1 & 1.7 & 4 & 180.7 & 1.8 & 4 \\
Indonesia & 126.1 & 1.2 & 3 & 97.5 & 0.9 & 2 \\
All Other & 162.7 & 1.6 & 4 & 209.6 & 2.1 & 5 \\
Total & $1,238.2$ & 12.0 & 27 & 1366.0 & 13.3 & 29 \\
\hline
\end{tabular}

Source: Pakistan Bureau of Statistics

The share of oil importing countries has fallen 3 to 2 percent in latest period mainly due to declining of oil prices (see table 1.3). Bilateral trade between Pakistan and trade partners description is given in Figure 1. Pakistan imports Petroleum products, Iron, steel manufactures, Machinery (non-electrical), Electrical goods, and Chemicals products, etc. In next few years, the construction related activities may increase in public sector spending, for the infrastructure of CPEC. However, this rigorous study tried to examine the pattern of Pakistans trade with its partners using the static and dynamic model.

\section{Literature Review}

Gravity models are extensively used in empirical research on bilateral trade. The first attempts elaborate the trade flows by the economic size of the trading partners and distance is closely related to the innovations (Leibenstein, 1966; Pöyhönen, 1963). The purpose of this paper is to test the impact of main characteristics of a country and its geographical location to its partners through bilateral trade flows. Recent developments in literature show that very limited studies have done this type of analysis on South Asia region. There are few studies that used the gravity model for the purpose of Pakistan. At first, we briefly discuss the major findings of few studies are related to Pakistan. This meticulous study will attempt to fill this gap.

Khan and Mahmood (2000) used gravity model and checked bilateral trade in Pakistan and controlling the size of economic, geographical location, and cultural proximity. The trade volume is taken as the regress and variable. The independent variables are the product of per capita GNPs, product of GNPs, real exchange rate, tariffs, distance, official language, border share, and regional dummies for instance; ASEAN, NAFTA, SAARC and EU. The model includes ten commodities for 21 countries and using interval data. All the coefficients showed to be highly statistically significant excluding bordering country, which gives negative sign. One of the reasons may be historical conflict occurred between India and Pakistan in the last 65 years.

Some studies have recycled the gravity to analyze the impact of trade blocks. Butt et al. (2008) used panel data including the SAARC countries for main 19 sectors of the Pakistan economy. The results indicate that higher weight of export potential with trading partner countries under the trade blocks. In case of Bangladesh, Rahman et al. (2006) also used gravity model for panel groups. His major findings show that the size of economies, trade openness, per capita GNP and distance involved in the bilateral trade are positively significant in regression analysis. Same as, Montanari et al. (2008) have supported the Rahman et al. (2006) model, revealed that higher income stock has robust effect on the trade and vice versa.

The classical and new trade theory briefly explains the world trade and nowadays gravity model performing tremendously in international trade. Similarly, report by Butt et al. (2008) based on gravity model at the various sector. Most of the time, export volume is taken as a dependent variable and many set of dummies variable are included such as, common border, common language, conflict, geographical location and tariffs, etc. The study covers 15 major sectors for the years 2002 and 2003 and identifies the trade potential of two states in the context of Pakistan and India region. According to the report results, the trade potential is higher, if both countries were not engaged in war conflicts and removed the barriers in bilateral trade. They showed that, beverages, chemicals and tobacco products, food, leather products and textiles have high exis- 
tence of trade potential.

In the first part of the gravity literature, we focus on Pakistan- related studies that discussed the international trade and in the second part international studies at World level have been taken into account. In most of the international level studies, export are taken as a dependent variable (Kong and Kneller, 2016; Suvankulov and Guc, 2012; Trotignon, 2010; Ullah and Inaba, 2012). Similarly, some other studies used import as dependent variable (Abiad et al., 2014; Tumbarello, 2006; Westerlund and Wilhelmsson, 2011). Bussière et al. (2008) took the average of imports and exports between the two countries as the dependent variables.

Similarly; GDP, per capita GDP of the trade partners as well as distance are used as independent variables in nearly all studies in the literature (Abiad et al., 2014; Ranajoy et al., 2006; Suvankulov and Guc, 2012; Ullah and Inaba, 2012; Westerlund and Wilhelmsson, 2011). Within this context, numerous other variables that can be involved in the gravity equations, which can explain the real picture of international trade of Pakistan. For example, in addition to gravity models, they added some "multilateral resistance variables" in the equation. Baier and Bergstrand (2009) used distance and border share as a proxy for trade costs. However, dummy variables for other factors that can affect trade volume, like geographical area, cultural proximately and as well as free trade agreements and economic blocks such as ASEAN, SAARC, NAFTA, WTO, $\mathrm{EU}, \mathrm{ECO}$, etc. were added to the gravity models over time (Ranajoy et al., 2006; Trotignon, 2010; Ullah and Inaba, 2012).

In a nutshell, there are a huge number of empirical applications in different studies which used gravity model. Thornton and Goglio (2002) emphasized on importance of economics size, distance and common language in regional trade for ASEAN and found significant results. See also Rahman et al. (2006) for Bangladesh; Babetskaia-Kukharchuk and Maurel (2003) for EU; Anaman and Al-Kharusi (2003) for Brunei; Blomqvist (2004) for Singapore; Batra (2006) for India; Baroncelli (2007) for Pakistan-India; Minetti et al. (2018) for UK-EU which provide an extensive discussion on the role of bilateral trade and found results according to economic theory.

\subsection{The Gravity Model}

The Newton physics law is the first vindication of the gravity. The model has been generated from Newton's Law of Gravity (Leibenstein, 1966; Pöyhönen, 1963) used for the first time in international trade. Over the last fifty years, the gravity model has become the workhorse of the trade researchers. According to the model, the trade volume between countries, directly depends on size of economics and inversely related to distance in gravity model (Anderson, 2011; Balassa,
1966; Caves, 1981; Leibenstein, 1966; Pöyhönen, 1963; Toh, 1982) and also consider that geographical distance is an important determinant of gravity model and distance is also the proxy for transportation cost. Similarly, Rauch (1999) and Eichengreen and Irwin (1998) emphasized on border, common language should be considered in gravity equation. So, using these variables; the gravity equation can be written as:

$$
T_{i j}=G \frac{M_{i}^{\alpha} M_{j}^{\beta}}{D_{I J}^{\delta}}
$$

Where $\mathrm{i}=$ Pakistan; $\mathrm{j}=1,2 \ldots . .11$ (trade partners); Tij denotes the flow from country i to j. Mi and $\mathrm{Mj}$ are the sizes of economy of Pakistan and trade partners, normally measured as the GDP or GDP per-capita. Dij is the geographically distance between two regions. $G$ is a constant term. We apply logs on the gravity equation and we estimate the linear gravity equation has the following form:

$$
L n T_{i j}=\ln G+\alpha \ln M_{j}+\beta \ln M_{j}-\delta \ln D_{i j}
$$

Where $\ln G$ represents the intercept, while $\alpha, \beta$ and $\delta$ are elasticities of the economic sizes and distance variables. The static econometric model of Pakistan's trade takes the following representation:

$$
Y_{i t}=\beta_{0}+\beta_{1} X_{i t}+\mu_{1}+\varepsilon_{i t}
$$

Where $Y_{i t}$ is set of Pakistan's export, import and bilateral trade respectively and $X_{i t}$ is a set of regressor variable. Most of the variables are in the $\log$ form; is the unobserved individual specific effects ${ }^{\prime} i$ is idiosyncratic error and assumed to beE $\left(_{i t}\right)=0$; $\operatorname{Var}\left({ }_{i t}\right)=\sigma^{2}$. One of the shortcomings of fixed effect model does not include the time invariant variable, for instance geographical distance. To overcome this problem, we used random effect and Tobit in static model. In static gravity model, random and Tobit give more accurate results (Verbeek, 2004); although, unlike theoretical models of trade, which do not advise a dynamic specification, we decided to introduce a variation in static model, because in this static model there are problems with correlation and endogeneity of few independent variables. These problems were resolved by Arellano and Bond (1991); Arellano and Bover (1995); Blundell and Bond (2000), who refined the first-differenced GMM model. In this paper, we used the GMM system estimator. The static model can be reworked in the following dynamic representation:

$$
Y_{i t}=\gamma Y_{i t-1}+\beta_{0}+\beta_{1} X_{i t}+\mu_{1}+\varepsilon_{i t}
$$

If yit-1 is not fixed rather a random variable and $\operatorname{Cov}\left(Y_{i t-1, i}\right) \neq 0$ then estimator is not biased but also 
asymptomatically biased, this problem has a solution called endogeneity problem, all problems can be solved easily with the instrumental variables techniques. In case of exact equation, GMM and 2SLS method produce same or identical results. In case of over identified equation, two methods produce different result and GMM is considered to be superior, but unfortunately in case of un- identified equation both methods fail to work. In short, both 2SLS and GMM are basically instrumental variable techniques. Consider now, take the 1 lag in the equation. However, we solved the issue of endogeneity.

$$
Y_{i t}=\gamma Y_{i t-2}+\beta_{0}+\beta_{1} X_{i t}+\mu_{1}+\varepsilon_{i t-1}
$$

If we subtract equation 5 from equation 4 , Then,

$$
\Delta Y_{i t}=\beta_{0}+\beta_{1} \Delta X_{i t}+\gamma \Delta Y_{i t-1}+\Delta \varepsilon_{i t}
$$

In equation 6 endogeneity has been bypassed, however, equation 5 shows that $\operatorname{Cov}($ Yit-1, Eit-1) $\neg 0$.Now we can easily estimate the GMM equation at level form, or 1 difference form by using different instrument variables. Now,

$$
\Delta Y_{i t-1}=\beta_{0}+\beta_{1} \Delta X_{i t-1}+\gamma \Delta Y_{i t-2}+\Delta \varepsilon_{i t-1}
$$

If we add one more difference in equation 7 , Then

$$
\Delta Y_{i t-1}=\beta_{0} \Delta X_{i t-2}+\gamma \Delta Y_{i t-3}+\Delta \varepsilon_{i t-2}
$$

Now you can solve the problem of endogeneity easily with difference equation. We apply the GMM principle, when number of moment condition can exceed the number of unknown parameter. In this method, we also minimize the sum of squares of the moments is also known as GMM estimator.

\section{Data description and Sources}

The data collected for the period of 2002 to 2015 and compiled from various sources. All variables are used per annum except border, and distance data. Pakistan's bilateral trades from other trading partners' data were collected from UN COMTRADE statistics. The Secondary data were collected from world development indicators (WDI),CEPII and http://globalization.kof.ethz.ch/. A specific description of the variables is given in table 3.1.

In our study, we used border dummy that equals 1 if the Pakistan shares a border with trade partners and 0 otherwise. In short, cultural proximity is indexing of three variables (Number of Ikea (per capita) and McDonald's Restaurants, Trade in books) same as; political globalization is also index of four variables (Membership in International Organizations, Embassies in Country, International Treaties and Participation in U.N. Security Council Missions) and each variable has different weight in the index. Similarly, generate the dummy of SAARC member of SAARC is equal 1 , otherwise 0 . A specific Correlation matrix is presented in Table 3.2.

\section{Empirical Results}

Table 4.3: Pakistan's Trade and Gravity: GMM-System

\begin{tabular}{lccc}
\hline Dependent Variable & Export & Import & Bilateral Trade \\
\hline Variables & GMM & GMM & GMM \\
\hline D.L1 & $0.71^{* * *}$ & $0.618^{* * *}$ & $0.701^{* * *}$ \\
& $(0.067)$ & $(0.069)$ & $(0.065)$ \\
Ln GDP & \\
& $-0.617^{* *}$ & 0.33 & 0.0525 \\
Ln GDP & $(0.292)$ & $(0.304)$ & $(0.279)$ \\
& -0.105 & 0.0353 & -0.148 \\
Political & $(0.164)$ & $(0.148)$ & $(0.128)$ \\
& $0.040^{* * *}$ & 0.001 & 0.010 \\
cultural & $(0.007)$ & $(0.008)$ & $(0.006)$ \\
& 0.006 & $0.019^{* * *}$ & $0.012^{* * *}$ \\
distance & $(0.003)$ & $(0.005)$ & $(0.004)$ \\
& -0.0001 & -1.3605 & 2.1603 \\
border & $(7.25)$ & $(5.74)$ & $(5.27)$ \\
& 0.514 & -0.466 & 0.338 \\
SAARC & $(0.616)$ & $(0.602)$ & $(0.517)$ \\
& 0.784 & $0.859^{* *}$ & 0.543 \\
Constant & $(0.546)$ & $(0.428)$ & $(0.381)$ \\
& $8.308^{* * *}$ & -1.496 & 1.519 \\
Observations & $(1.477)$ & $(1.730)$ & $(1.663)$ \\
Wald chi ${ }^{2}$ & 143 & 143 & 143 \\
\hline Notes: Standard & $438.28^{* * *} 699.79^{* * *}$ & $710.02^{* * *}$ \\
p errors in parentheses, & $* * *$ & $p<0.01, * *$ \\
& & &
\end{tabular}

As a starting point, we used some time invariant variable in econometric gravity model, so fixed effects models suffer from a technical issue in the gravity model. However, it became statistically consistence, implying that random effects and Tobit and GMM model, because they all remove the econometric issues. The results of random effects are reported in Table 4.1.

There are three different types of models, one is export, second is import and third is the bilateral trade model which is mostly known as the trade volume. The random effect model performs well, explaining up to 50 per cent of sample variation in the Pakistan's bilateral trade. The size of economic results is consistent under the random effects, both coefficients are highly 
Table 3.1: Descriptive statistics of Selected Regions

\begin{tabular}{llcccc}
\hline Variables & Definition & Mean & S.D & Min & Max \\
\hline Export & Export flows come to the rest of the world(\$ Million) & 812.9 & 1,093 & 32 & 4,300 \\
Import & import flows come from the rest of the world(\$ Million) & 1,965 & 1,949 & 30 & 11,000 \\
Bilateral Trade & Bilateral trade between Pakistan and trade partners (\$ Milllion) & 2,778 & 2,479 & 209 & 12,900 \\
GDPi & GDP per capita, PPP (current international \$) & 8.291 & 0.161 & 7.975 & 8.519 \\
GDPk & GDP per capita, PPP (current international \$) & 9.926 & 1.28 & 6.797 & 11.41 \\
Cultural proximity & Index of three variables & 65.66 & 35.07 & 1 & 97.14 \\
Political globalization & Index of four variables & 71.42 & 16.28 & 37.25 & 93.71 \\
Distance & Geographical Distance & 3,050 & 3,283 & 0 & 11,092 \\
Border & Border share=1, otherwise=0 & 0.636 & 0.483 & 0 & 1 \\
SAARC & Member of SAARC=1, otherwise=0 & 0.182 & 0.387 & 0 & 1 \\
\hline
\end{tabular}

Source: Pakistan Bureau of Statistics

Table 3.2: Correlation Matrix

\begin{tabular}{lccccccc}
\hline & GDPi & GDP $_{k}$ & Political & Cultural & Distance & Border & SAARC \\
\hline GDPi & 1 & & & & & & \\
GDP $_{k}$ & 0.1388 & 1 & & & & & \\
Political & 0.1502 & 0.0336 & 1 & & & & \\
Cultural & 0.0448 & 0.7619 & 0.2327 & 1 & & & \\
Distance & -0.0189 & 0.5165 & 0.4388 & 0.5589 & 1 & & \\
Border & 0 & 0.8444 & 0.0115 & 0.8171 & 0.6848 & 1 & \\
SAARC & 0 & -0.8126 & -0.116 & -0.6584 & -0.4146 & -0.6236 & 1 \\
\hline
\end{tabular}

significant at $1 \%$ in Pakistan's bilateral trade and import model and local size of economic is not matter for export. This indicates that size of economic promotes bilateral trade and especially, import. Other supporting variables political globalization and distance both are significant but in case of Pakistan only geographical distance coefficient positive significant at $10 \%$ in first two cases and $5 \%$ significantly at the bilateral trade. The coefficient of the political globalization in random effect model is statistical significantly at $5 \%$ in gravity model. Similarly, the coefficient of cultural proximity, border share and SAARC is no importance for Pakistan's export, import, and bilateral trade model.

The results support the real facts in tobit regression model in table 4.2. As for the export models, the partner GDP raises the export of Pakistan among the partner countries, it determined the export of goods. Overall, this indicator has led to positive effects on Pakistan trade, showing up fairly positive effects on export, import and bilateral trade of the Pakistan's economy. Similarly, local GDP does not matter for the export, but significantly contributes to the import and even bilateral trade at $1 \%$. The results also show that all export, import, and bilateral trade are pay role of political factors; it is significant at 1 per cent in all cases. The distance also matters in bilateral trade; it determined the cost of transportation. When cost of transportation is high, the trade will go down. The cultural, SAARC and border share have insignificant effects in all dynamic model.

The next section will report the GMM results with first-differenced in table 4.3. The coefficients of export, import and bilateral trade are significant on own lag at $1 \%$.Another interesting finding is that coefficients of the size of economics of Pakistan is negatively significant at $5 \%$, but economic size of trade partners is insignificant in all cases. Similarly, trade partner GDP 
Table 4.1: Pakistan's trade and Gravity: Random Effects

\begin{tabular}{lccc}
\hline Dependent Variables & Export & Import & Bilateral Trade \\
\hline Variables & Random Effects & Random Effects & Random Effects \\
\hline Ln $G D P_{i}$ & -0.0301 & $1.596^{* * *}$ & $1.379^{* * *}$ \\
& $(0.366)$ & $(0.336)$ & $(0.317)$ \\
Ln GDP $P_{k}$ & $1.105^{* * *}$ & $0.553^{* * *}$ & $0.592^{* * *}$ \\
& $(0.205)$ & $(0.192)$ & $(0.180)$ \\
Political & $0.0333^{* * *}$ & $0.0349^{* * *}$ & $0.0276^{* * *}$ \\
& $(0.012)$ & $(0.010)$ & $(0.0105)$ \\
cultural & -0.004 & 0.0004 & -0.0009 \\
& $(0.005)$ & $(0.005)$ & $(0.005)$ \\
distance & $-0.0001^{*}$ & $-0.0001^{*}$ & $-0.0001^{* *}$ \\
& $(7.910)$ & $(6.750)$ & $(6.590)$ \\
border & -0.586 & 0.275 & 0.341 \\
& $(1.338)$ & $(0.844)$ & $(0.910)$ \\
SAARC & 2.391 & -0.063 & 0.964 \\
& $(1.553)$ & $(0.894)$ & $(1.005)$ \\
Constant & $7.242^{* * *}$ & $-13.98^{* * *}$ & $-11.68^{* * *}$ \\
& $(2.119)$ & $(1.838)$ & $(1.750)$ \\
$R^{2}$ & 0.48 & 0.54 & 0.62 \\
Observations & 154 & 154 & 154 \\
Country Effect & Yes & Yes & Yes \\
Year Effect & Yes & Yes & Yes \\
\hline
\end{tabular}

Notes: Standard errors in parentheses, ${ }^{* *} p<0.01,{ }^{* *} p<0.05,{ }^{*} p<0.1$ respectively.

Table 4.2: Pakistan's Trade and Gravity: Tobit Model

\begin{tabular}{lccc}
\hline Dependent Variable & Export & Import & Bilateral Trade \\
\hline Variables & Tobit Regression & Tobit Regression & Tobit Regression \\
\hline Ln GDP $i$ & -0.046 & $1.598^{* * * *}$ & $1.392^{* * * *}$ \\
& $(0.3590$ & $(0.32)$ & $(0.311)$ \\
Ln GDP & $1.112^{* * *}$ & $0.540^{* * *}$ & $0.585^{* * *}$ \\
& $(0.20)$ & $(0.184)$ & $(0.176)$ \\
Political & $0.033^{* * *}$ & $0.034^{* * *}$ & $0.027^{* * *}$ \\
& $(0.012)$ & $(0.009)$ & $(0.010)$ \\
cultural & -0.004 & 0.001 & -0.0007 \\
& $(0.005)$ & $(0.005)$ & $(0.004)$ \\
distance & $-0.0001^{* *}$ & $-0.0001^{* *}$ & $-0.0001^{* *}$ \\
& $(7.940)$ & $(6.380)$ & $(6.420)$ \\
border & -0.565 & 0.287 & 0.329 \\
& $(1.387)$ & $(0.722)$ & $(0.850)$ \\
SAARC & 2.407 & -0.051 & 0.954 \\
& $(1.622)$ & $(0.729)$ & $(0.927)$ \\
Constant & $7.282^{* * *}$ & $-13.89^{* * *}$ & $-11.70^{* * *}$ \\
& $(2.101)$ & $(1.766)$ & $(1.694)$ \\
Observations & 154 & 154 & 154 \\
sigma_u & $1.579^{* * *}$ & $0.648^{* * *}$ & $0.869^{* * *}$ \\
& $(0.349)$ & $(0.157)$ & $(0.195)$ \\
sigma_e & $0.383^{* * *}$ & $0.379^{* * *}$ & $0.345^{* * *}$ \\
& $(0.022)$ & $(0.022)$ & $(0.020)$ \\
Wald chi ${ }^{2}$ & $126.27^{* * *}$ & $247.53^{* * *}$ & $229.31^{* * *}$ \\
\hline
\end{tabular}

Notes: Standard errors in parentheses, ${ }^{* *} p<0.01,{ }^{* *} p<0.05,{ }^{*} p<0.1$

is no important in GMM results. Our export depends on the political globalization that will raise and fall through this channel, this factors is not much important in case of import and bilateral trade model. Our results also show that exports do not promote on the basis of cultural proximity coefficient, which is statistically insignificant, but interesting our imports also increase on the cultural proximity basis. The geographical distance and border share and partner economic size have insignificant effects in all dynamic model. Similarly, the 
coefficients of SAARC organization have significant effect during import model but not crucial for export and bilateral trade model.

\section{Conclusions}

The purpose of this paper was to analyze the determinants of Pakistan's bilateral trade flows to the major 11 trading partners by using a gravity model for the period of 2002 to 2015. We applied a tobit, and random effects for the analyses. In this research, we also use a dynamic panel (GMM estimator) to overcome the issues of correlation, time invariant variables, heteroskedasticity and endogeneity for some predictor variables (Baltagi, 2008). When we use Tobit, random effect, and GMM models, the economic size of Pakistan and trade partners have significant effect on Pakistan's export, import and bilateral trade, indicating that developed countries do indeed more trade then the under developed countries. The remaining variables were little bit affect. The results are according to the literature (Anderson, 2011; Batra, 2006; De, 2013; Faustino and Proença, 2011; Kabir and Salim, 2010; Leitao and Tripathi, 2013; Prehn et al., 2016; Ranajoy et al., 2006). The results conclude that local sizes of economy enhance export, import and bilateral trade; while international economic mass is important for Pakistan; trade decreases when distance between two partners increases. The estimated results are consistent with the theoretical models, Pakistan' trade partners with economic masses, political globalization, and distance have strong impact through trade.

\section{References}

Abiad, A., Mishra, P., and Topalova, P. (2014). How does trade evolve in the aftermath of financial crises? IMF Economic Review, 62(2):213-247.

Anaman, K. A. and Al-Kharusi, L. H. (2003). An analysis of trade flows between brunei darussalam and the european union. ASEAN Economic Bulletin, pages 60-72.

Anderson, J. E. (2011). The gravity model. Annu. Rev. Econ., 3(1):133-160.

Arellano, M. and Bond, S. (1991). Some tests of specification for panel data: Monte carlo evidence and an application to employment equations. The review of economic studies, 58(2):277-297.

Arellano, M. and Bover, O. (1995). Another look at the instrumental variable estimation of error-components models. Journal of econometrics, 68(1):29-51.

Babetskaia-Kukharchuk, O. and Maurel, M. (2003). Accession to the wto and eu enlargement: what potential for trade increase?
Baier, S. L. and Bergstrand, J. H. (2009). Bonus vetus ols: A simple method for approximating international trade-cost effects using the gravity equation. Journal of International Economics, 77(1):77-85.

Balassa, B. (1966). Tariff reductions and trade in manufacturers among the industrial countries. The American Economic Review, 56(3):466-473.

Baltagi, B. (2008). Econometric analysis of panel data. John Wiley \& Sons.

Baroncelli, E. (2007). The peace dividend,safta, and pakistanindia trade. The Challenges and Potential of Pakistan-India Trade, 59.

Batra, A. (2006). India's global trade potential: The gravity model approach. Global Economic Review, 35(3):327-361.

Blomqvist, P. (2004). The choice revolution: privatization of swedish welfare services in the 1990s. Social policy $\mathcal{E}$ administration, 38(2):139-155.

Blundell, R. and Bond, S. (2000). Gmm estimation with persistent panel data: an application to production functions. Econometric reviews, 19(3):321-340.

Bussière, M., Fidrmuc, J., and Schnatz, B. (2008). Eu enlargement and trade integration: Lessons from a gravity model. Review of Development Economics, 12(3):562-576.

Butt, W. A. et al. (2008). Pakistan's export potential: A gravity model analysis. Technical report, State Bank of Pakistan, Research Department.

Caves, R. E. (1981). Intra-industry trade and market structure in the industrial countries. Oxford Economic Papers, 33(2):203-223.

De, P. (2013). Assessing barriers to trade in services in india: An empirical investigation. Journal of Economic Integration, pages 108-143.

Eichengreen, B. and Irwin, D. A. (1998). The role of history in bilateral trade flows. In The regionalization of the world economy, pages 33-62. University of Chicago Press.

Faustino, H. C. and Proença, I. (2011). Effects of immigration on intra-industry trade: a logit analysis.

Kabir, M. and Salim, R. (2010). Can gravity model explain bimstec's trade? Journal of Economic Integration, pages 143165.

Khan, A. H. and Mahmood, Z. (2000). Pakistan and Emerging Global Trading Environment: Challenges and Opportunities. Vanguard.

Kong, Y. F. and Kneller, R. (2016). Measuring the impact of china's export growth on its asian neighbours. The World Economy, 39(2):195-220.

Leibenstein, H. (1966). Shaping the world economy: suggestions for an international economic policy.

Leitao, N. C. and Tripathi, S. (2013). Portuguese trade and european union: The gravity model. 
Minetti, R., Mulabdic, A., Ruta, M., and Zhu, S. (2018). Are banks engines of export? financial structures and export dynamics.

Montanari, I., Nelson, K., and Palme, J. (2008). Towards a european social model? trends in social insurance among eu countries 1980-2000. European Societies, 10(5):787-810.

Pöyhönen, P. (1963). A tentative model for the volume of trade between countries. Weltwirtschaftliches Archiv, pages 93-100.

Prehn, S., Brümmer, B., and Glauben, T. (2016). Gravity model estimation: fixed effects vs. random intercept poisson pseudo-maximum likelihood. Applied Economics Letters, 23(11):761-764.

Rahman, M., Shadat, W. B., Das, N. C., et al. (2006). Trade potential in safta: An application of augmented gravity model. CPD occasional paper series, 61:512.

Ranajoy, B., Banerjee, T., et al. (2006). Does the gravity model explain india direction of trade? a panel data approach. Technical report, Indian Institute of Management Ahmedabad, Research and Publication Department.

Rauch, J. E. (1999). Networks versus markets in international trade. Journal of international Economics, 48(1):7-35.

Samy, Y. and Dehejia, V. H. (2011). Trade and labor standards in the european union: A gravity model approach. The International Trade Journal, 25(5):581-618.

Serrano, R. 1. and Pinilla, V. (2012). The long-run decline in the share of agricultural and food products in international trade: a gravity equation approach to its causes. Applied Economics, 44(32):4199-4210.
Suvankulov, F. and Guc, Y. (2012). Who is trading well in central asia? a gravity analysis of exports from the regional powers to the region. Eurasian Journal of Business and Economics, 5(9):21-43.

Thornton, J. and Goglio, A. (2002). Regional bias and intraregional trade in southeast asia. Applied Economics Letters, 9(4):205-208.

Toh, K. (1982). A cross-section analysis of intra-industry trade in us manufacturing industries. Weltwirtschaftliches Archiv, 118(2):281-301.

Trotignon, J. (2010). Does regional integration promote the multilateralization of trade flows? a gravity model using panel data. Journal of Economic Integration, pages 223-251.

Tumbarello, P. (2006). Are regional trade agreements in asia stumbling or building blocks? some implications for the mekong countries. In seminar on Accelerating Development in the Mekong Regionthe Role of Economic Integration, Siem Reap, Cambodia, June, pages 26-27.

Ullah, M. S. and Inaba, K. (2012). Impact of rta and pta on bangladeshs export: application of a gravity model. Journal of Industry, Competition and Trade, 12(4):445-460.

Verbeek, M. (2004). A guide to modern econometrics (2nd [rev. and updated] ed.). chichester [etc.].

Westerlund, J. and Wilhelmsson, F. (2011). Estimating the gravity model without gravity using panel data. Applied Economics, 43(6):641-649.

Xuegang, C. (2008). Study on xinjiangs bilateral trade using a gravity model. Asia Europe Journal, 6(3-4):507-517. 